\title{
REVIEW
}

\section{Are activity promotion interventions based on the transtheoretical model effective? A critical review}

\section{J Adams, M White}

Br J Sports Med 2003;37:106-1 14

The health benefits of physical activity are well documented yet $70 \%$ of adults remain sedentary. It has been suggested that inverventions based on the transtheoretical model of behaviour change (TTM) may be useful in promoting physical activity. Published work on the effectiveness of such inteventions is therefore critically reviewed. Although there is evidence that TTM based activity promotion interventions are effective in promoting activity adoption, initial results on longer term adherence are disappointing.

Correspondence to: Dr Adams, School of Population and Health Sciences, The Medical School, Newcastle upon Tyne NE2 4HH, UK; i.m.adams@ncl.ac.uk

Accepted

5 November 2002

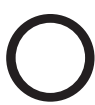
ptimum activity levels can delay or prevent the development of ischaemic heart disease, type 2 diabetes mellitus, obesity, hypertension, colon cancer, osteoporosis, anxiety, depression, and the institutionalisation of elderly people. ${ }^{1}$ In the United Kingdom, current recommendations for the maximisation of health are that "every adult should accumulate 30 minutes or more of moderate intensity physical activity on most, preferably all, days of the week". ${ }^{2}$ However, typically, only about one third of adults in developed countries meet these recommendations. ${ }^{3}$

The transtheoretical model of behaviour change (TTM) was first described in 1982 as a proposed mechanism of smoking cessation. ${ }^{4}$ Understanding behaviour change as a process rather than a single event, the TTM attempts to explain how, rather than why, behaviour change occurs. Unlike previous behavioural models, it takes a pragmatic approach and offers explicit suggestions for how people can be helped to change their behaviour. With current adaptations, the TTM states that there are five distinct stages involved in long term behaviour change (table 1) during which 10 different processes of change $^{5}$ may be used. Figure 1 shows the interaction of the stages and processes of change. The TTM suggests that, for successful behaviour change, interventions must be tailored to a person's current stage of change and make use of the appropriate processes of change.

Traditional interventions to improve physical activity participation have had some short term success but have been minimally effective in achieving long term activity adherence. ${ }^{6}$ Although the TTM was originally developed to explain smoking cessation behaviour, its application to the uptake of physical activity has been confirmed. ${ }^{78}$ This, and its success in helping people change other unhealthy behaviours, particularly smoking, ${ }^{9}$ has led to recommendations for its use in activity promotion. ${ }^{6}$ This paper critically reviews published reports of TTM based, activity promotion interventions and attempts to answer the question: is there evidence of an additional effect of TTM based activity promotion interventions over non-staged interventions?

\section{METHODS}

To identify relevant papers for inclusion in the review, we searched the Medline and PsycINFO databases from 1982 (when the TTM was first described $^{4}$ ) to 2001 using the keywords "transtheoretical" OR "stages of change" AND "activity" OR "exercise".

Papers identified by these searches that met the following criteria were included.

- An intervention explicitly based on the TTM that aimed to promote physical activity levels was described and evaluated

- Study participants were adult (more than 16 years of age) and living within the community

- Some assessment of physical activity levels both before and after implementation of the intervention was included

- English language

- Publication between 1982 and 2001 inclusive.

The presence of a control group was not a specific criterion for inclusion in the present review.

This process identified 10 relevant papers. A further 16 that also met the above criteria were identified from scrutinising the reference lists of the 10 papers identified by electronic searches. Thus a total of 26 papers were identified for inclusion in the review.

\section{FINDINGS}

Table 2 summarises the 26 papers documenting 16 intervention programmes; they are discussed briefly below. Overall, seven programmes used TTM based counselling only, four used TTM based written materials only, and five used a mixture of TTM based counselling and written information. In the short term (six months or less), 11 of 15 $(73 \%)$ programmes reported some significant benefit of TTM based interventions over control conditions-in terms of stage progression, activity levels, or both. One further study ${ }^{11}$ was not controlled, but reported an effect of the intervention over characteristics at baseline. Longer term (more than six months), two of seven (29\%) programmes reported some benefit of TTM based programmes. We used more than six months as our definition of long term because, by definition, six months must have elapsed before a person can be classified as being in the maintenance stage of activity change (table 1). 
Table 1 Definitions of the stages of activity change ${ }^{8}$

\begin{tabular}{ll}
\hline Stage & Definition \\
\hline $\begin{array}{l}\text { Pre-contemplation } \\
\text { Contemplation }\end{array}$ & $\begin{array}{l}\text { Individuals are not participating in any physical activity and have no intention to do so in the future } \\
\text { Individuals are not participating in any physical activity but intend to start doing so in the next six months } \\
\text { Individuals intend to start participating in regular physical activity in the next six months and are starting to make small changes in } \\
\text { their activity behaviour }\end{array}$ \\
$\begin{array}{l}\text { Action } \\
\text { Maintenance }\end{array}$ & $\begin{array}{l}\text { Individuals meet defined criteria* for physical activity but have done so for less than six months } \\
\text { *Different authors use different criteria for defining acceptable levels of physical activity; these are often related to current activity recommendations. }\end{array}$
\end{tabular}

\section{Study of Marcus et al ${ }^{11}$}

This uncontrolled study used a before and after comparison design to assess the effects of stage specific, written activity promotion information. It recruited subjects through an advertising campaign and therefore participants were probably unusually motivated and not representative of the sedentary population in general. ${ }^{8}$ However, short term effects of the intervention were seen in terms of both stage progression and activity levels.

\section{Fresh start ${ }^{12}$}

This study represented a pragmatic attempt to modify cardiovascular risk using TTM based videoed counselling and written information. Doctors were asked to devise and implement their own methods of recruiting suitable subjects. Although this represents what may happen in "real life", it led to inconsistencies in recruitment procedures and significant intergroup differences in key variables at baseline.

Furthermore, all subjects, independent of their stage of activity change, were shown the same intervention videosone for each risk factor (obesity, hypertension, and hypercholesterolaemia). It seems unlikely that a single intervention such as this could be truly stage matched.

Finally, the "high risk" approach adopted by this study runs counter to both accepted wisdom ${ }^{13}$ and TTM philosophy. The TTM proposes that everyone, no matter what their motivational readiness to change, can be helped to adopt or maintain healthier behaviours. Targeting only those who are at "high risk" of cardiovascular disease ignores this important innovation.

\section{Study of Cardinal and Sachs ${ }^{14}$}

This study trialled stage specific, written, activity promotion interventions, which advocated either structured or lifestyle activity. As with all single worksite interventions, there was a risk in this study of contamination between the intervention and control group. The study recruited only working, high school educated women, making the results difficult to generalise to the wider sedentary population.

Physical activity levels were not measured in this study, and stage of activity change was the only outcome measure. Although stage of activity change is an important variable, it is activity, rather than stage of change, that affects health. Stage progression does not necessarily result in increased physical activity levels (table 1) and cannot be assumed to be a good proxy for physical activity.

\section{Study of Loughlan and Mutrie ${ }^{41}$}

This study assessed the use of exercise consultations compared with traditional fitness assessment and feedback, and non-staged, written information in subjects originally in the contemplation and preparation stages of activity change. The authors propose that these people are most likely to respond to a staged intervention. As mentioned above, this contradicts TTM theory, which states that everyone can

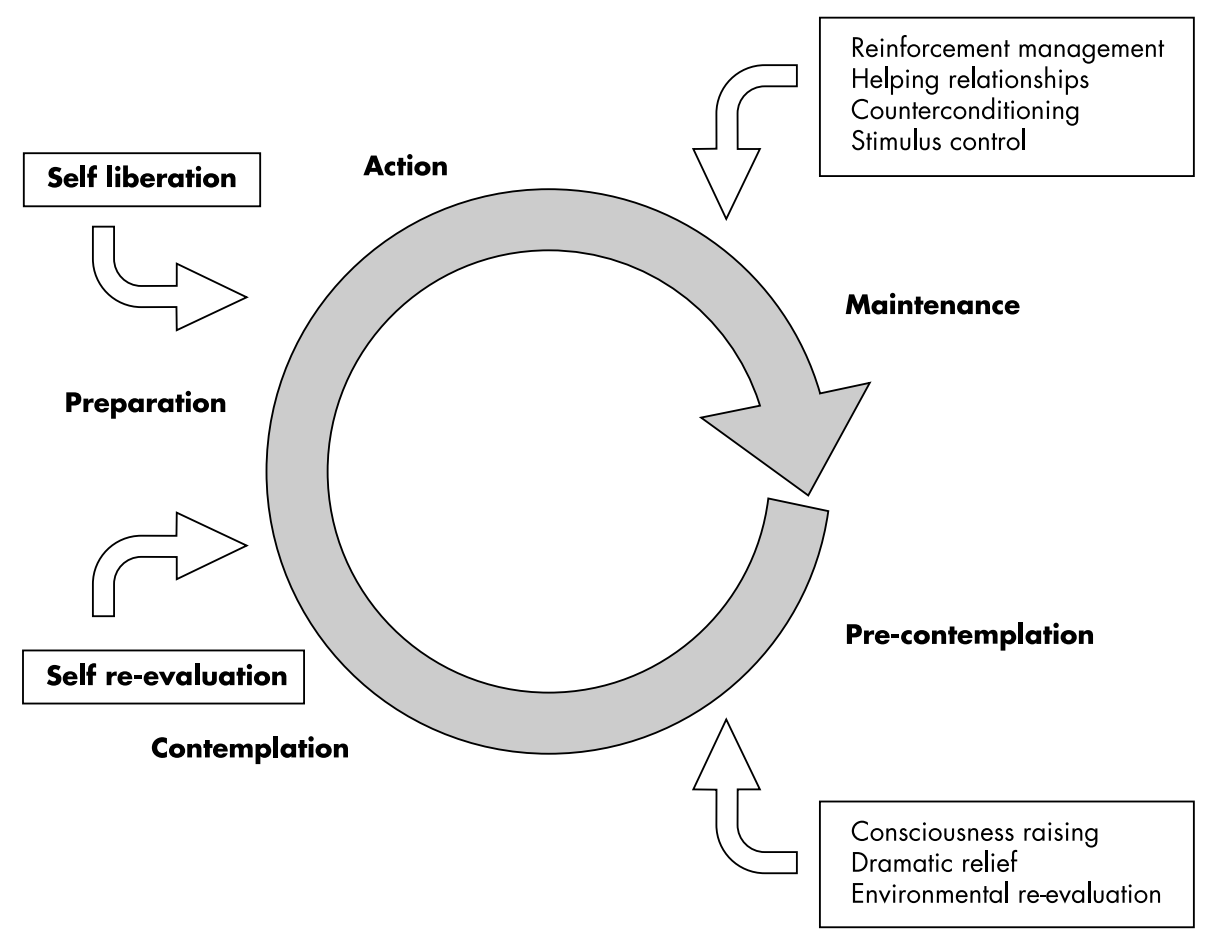

Figure 1 The transtheoretical model of behaviour change; stages are shown in bold, and processes in boxes. 
Table 2 Summary of studies reviewed

\begin{tabular}{|c|c|c|c|c|c|c|c|c|c|}
\hline \multirow[b]{2}{*}{ Project } & \multirow[b]{2}{*}{$\begin{array}{l}\text { Nature of sample completing } \\
\text { study }\end{array}$} & \multirow[b]{2}{*}{ Country } & \multirow[b]{2}{*}{ Design } & \multirow[b]{2}{*}{ Experimental intervention } & \multirow[b]{2}{*}{ Control condition } & \multirow[b]{2}{*}{$\begin{array}{l}\text { Follow up } \\
\text { period }\end{array}$} & \multirow[b]{2}{*}{ Results } & \multicolumn{2}{|c|}{ Effective* } \\
\hline & & & & & & & & $\begin{array}{l}\text { Short } \\
\text { term** }\end{array}$ & $\begin{array}{l}\text { Long } \\
\text { term }\end{array}$ \\
\hline Marcus ef a l $^{11}$ & $\begin{array}{l}236 \text { of } 610(39 \%) \text { adults in } \\
\text { contemplation, preparation and } \\
\text { action stages of activity change, } \\
\text { recruited via advertising } \\
\text { campaign. Follow up results } \\
\text { from stratified random sample of } \\
\text { participants. }\end{array}$ & USA & $\begin{array}{l}\text { Before and after, } \\
\text { uncontrolled }\end{array}$ & $\begin{array}{l}\text { Stage specific written activity } \\
\text { information on how to start and } \\
\text { continue physical activity and leisure } \\
\text { facilities in area - one pamphlet for } \\
\text { each stage of change. }\end{array}$ & $\mathrm{N} / \mathrm{A}$ & 6 weeks & $\begin{array}{l}\text { Subjects significantly more active after } \\
\text { intervention than before }(p<0.0001) .62 \% \text { of } \\
\text { those originally in contemplation stage and } \\
61 \% \text { of those originally in preparation stage } \\
\text { showing stage progression. } 9 \% \text { of those } \\
\text { originally in action stage showed stage } \\
\text { regression. }\end{array}$ & Yes & N/A \\
\hline Fresh start $^{12}$ & $\begin{array}{l}382 \text { of } 758(50 \%) \text { adults with } \\
\geqslant 1 \text { modifiable cardiovascular } \\
\text { risk factors (BMl>25 kg/m }{ }^{2}, \\
\text { blood pressure> } 140 / 95 \mathrm{~mm} \\
\mathrm{Hg} \text {, cholesterol }>5.5 \mathrm{mmol} / \mathrm{l}, \\
\text { current smoker) recruited in } \\
\text { primary care using methods } \\
\text { devised and identified as } \\
\text { suitable by individual physicians }\end{array}$ & UK & $\begin{array}{l}\text { Randomised (by } \\
\text { GP practice), } \\
\text { controlled }\end{array}$ & $\begin{array}{l}\text { TTM based videoed activity } \\
\text { counselling +/- TTM based written } \\
\text { information - one video and } \\
\text { information leaflet per risk factor }\end{array}$ & $\begin{array}{l}\text { Routine care - assessment of } \\
\text { cardiovascular risk with } \\
\text { appropriate, routine feedback }\end{array}$ & $\begin{array}{l}4-6 \text { months } \\
\text { and } 12-18 \\
\text { months }\end{array}$ & $\begin{array}{l}\text { Significant increase in energy expenditure in } \\
\text { all groups but no difference between groups } \\
\text { (figures not given). } \\
\text { At } 4 \text { months, } 20 \% \text { of those in intervention } \\
\text { groups and } 27 \% \text { of those in control group } \\
\text { ( }=0.02 \text { ) showed stage progression } \\
\text { At } 12 \text { months, } 20-22 \% \text { of subjects in all } \\
\text { groups made stage progression }(p=0.81) \text {. }\end{array}$ & No & No \\
\hline $\begin{array}{l}\text { Cardinal and } \\
\text { Sachs }^{14}\end{array}$ & $\begin{array}{l}81 \text { of } 113(72 \%) \text { female } \\
\text { university clerical staff in all } \\
\text { stages of activity change. } \\
\text { Recruitment method not } \\
\text { described. }\end{array}$ & USA & $\begin{array}{l}\text { Stratified (by } \\
\text { baseline stage of } \\
\text { activity change), } \\
\text { randomised (by } \\
\text { individual), } \\
\text { controlled }\end{array}$ & $\begin{array}{l}\text { Stage specific written information } \\
\text { promoting structured (traditional } \\
\text { exercise classes and sessions) or } \\
\text { lifestyle (integrating exercise into } \\
\text { daily routine) activity using TTM } \\
\text { theory }\end{array}$ & $\begin{array}{l}\text { Non-staged written feedback } \\
\text { on current activity levels }\end{array}$ & $\begin{array}{l}1 \text { and } 7 \\
\text { months }\end{array}$ & $\begin{array}{l}\text { Significant stage progression in all groups at } 1 \\
\text { and } 7 \text { months ( } p<0.05 \text { ). No intergroup } \\
\text { differences. } \\
\text { At } 1 \text { month, of those who could show stage } \\
\text { progression (i.e. not in maintenance stage at } \\
\text { baseline), } 39 \% \text { did. } \\
\text { At } 7 \text { months, } 57 \% \text { of subjects who could show } \\
\text { stage progression did, } 30 \% \text { maintained their } \\
\text { original stage and } 13 \% \text { regressed. }\end{array}$ & No & No \\
\hline $\begin{array}{l}\text { Loughlan and } \\
\text { Mutrie }^{41}\end{array}$ & $\begin{array}{l}\text { Unknown number completed of } \\
179 \text { recruited. Sedentary adults } \\
\text { in preparation and } \\
\text { contemplation stage recruited in } \\
\text { workplace }\end{array}$ & UK & $\begin{array}{l}\text { Randomised (by } \\
\text { individual), } \\
\text { controlled }\end{array}$ & $\begin{array}{l}\text { 'Exercise consultation' (a } 30 \text { minute, } \\
\text { one-to-one consultation based in TTM } \\
\text { theory), delivered by trained } \\
\text { research assistants }\end{array}$ & $\begin{array}{l}\text { Fitness assessment and } \\
\text { feedback or written activity } \\
\text { information (unstaged) }\end{array}$ & $\begin{array}{l}1,3 \text { and } 6 \\
\text { months }\end{array}$ & $\begin{array}{l}\text { All subjects increased number of hours of } \\
\text { exercise per week from } 3.5 \text { hours at baseline, } \\
\text { to } 6.75 \text { hours at } 1 \text { month, to } 6 \text { hours at } 3 \\
\text { months and } 5 \text { hours at } 6 \text { months }(p<0.001) \text {. } \\
\text { No intergroup differences }\end{array}$ & No & N/A \\
\hline $\begin{array}{l}\text { Project PACE - } \\
1^{16-18}\end{array}$ & $\begin{array}{l}212 \text { of } 255(83 \%) \text { adults in } \\
\text { contemplation stage of activity } \\
\text { change recruited in primary care } \\
\text { by telephone assessment of all } \\
\text { those booked for non-acute visits } \\
\text { over study period }\end{array}$ & USA & $\begin{array}{l}\text { Non-randomised, } \\
\text { controlled }\end{array}$ & $\begin{array}{l}\text { Stage specific activity counselling } \\
\text { delivered by trained physician, } \\
\text { selected for interest in activity } \\
\text { counselling, following written stage } \\
\text { assessment completed in waiting } \\
\text { room, and follow up phone call } \\
\text { delivered by research team }\end{array}$ & $\begin{array}{l}\text { Routine care - from } \\
\text { physicians selected for lack of } \\
\text { interest in activity counselling, } \\
\text { given training in hepatitis B } \\
\text { diagnosis and treatment }\end{array}$ & $4-6$ weeks & $\begin{array}{l}\text { Significantly more stage progression in } \\
\text { intervention compared with control subjects } \\
\text { (figures not given). } 52 \% \text { of intervention } \\
\text { subjects regularly active at follow up compared } \\
\text { with } 12 \% \text { of control subjects. Intervention } \\
\text { subjects reported } 40 \text { min increase in time spent } \\
\text { walking per week compared with } 10 \text { min } \\
\text { increase in control subjects }(p<0.05)\end{array}$ & Yes & N/A \\
\hline $\begin{array}{l}\text { Project PACE - } \\
2^{19}\end{array}$ & $\begin{array}{l}822 \text { of } 847(97 \%) \text { adults in all } \\
\text { stages of activity change } \\
\text { recruited in primary care by } \\
\text { telephone assessment of all } \\
\text { those booked to attend for a } \\
\text { non-acute visit over the study } \\
\text { period }\end{array}$ & USA & $\begin{array}{l}\text { Randomised (by } \\
\text { physician), } \\
\text { controlled }\end{array}$ & $\begin{array}{l}\text { Stage specific activity counselling } \\
\text { delivered by trained physician } \\
\text { following written stage assessment in } \\
\text { waiting room + follow up 'phone call } \\
\text { at } 1 \text { month from research assistant } \\
+/- \text { follow up phone calls at } 2,3 \\
\text { and } 4 \text { months and postcard } \\
\text { reminders at } 2,3,4 \text { and } 5 \text { months }\end{array}$ & $\begin{array}{l}\text { Routine care from physicians } \\
\text { receiving minimal information } \\
\text { on study (physicians randomly } \\
\text { allocated to intervention or } \\
\text { control groups) }\end{array}$ & 6 months & $\begin{array}{l}\text { No overall intergroup differences in physical } \\
\text { activity variables. Overall significantly more } \\
\text { stage progression in intervention than control } \\
\text { group: } 33 \% \text { ( } p=0.05 \text { ) more contemplators } \\
\text { made stage progression in intervention } \\
\text { compared to control group. }\end{array}$ & Yes & N/A \\
\hline
\end{tabular}




\section{Table 2 continued}

\begin{tabular}{|c|c|c|c|c|c|c|c|c|c|}
\hline \multirow[b]{2}{*}{ Project } & \multirow[b]{2}{*}{$\begin{array}{l}\text { Nature of sample completing } \\
\text { study }\end{array}$} & \multirow[b]{2}{*}{ Country } & \multirow[b]{2}{*}{ Design } & \multirow[b]{2}{*}{ Experimental intervention } & \multirow[b]{2}{*}{ Control condition } & \multirow[b]{2}{*}{$\begin{array}{l}\text { Follow up } \\
\text { period }\end{array}$} & \multirow[b]{2}{*}{ Results } & \multicolumn{2}{|c|}{ Effective* } \\
\hline & & & & & & & & $\begin{array}{l}\text { Short } \\
\text { term** }\end{array}$ & $\begin{array}{l}\text { Long } \\
\text { term }\end{array}$ \\
\hline $\begin{array}{l}\text { Physically } \\
\text { active for } \\
\text { life }{ }^{2-22}\end{array}$ & $\begin{array}{l}322 \text { of } 355(91 \%) \text { sedentary } \\
\text { subjects over } 50 \text {, recruited in } \\
\text { primary care by telephone } \\
\text { assessment of all those booked } \\
\text { to attend for a non-acute visit } \\
\text { over the study period }\end{array}$ & USA & $\begin{array}{l}\text { Randomised (by } \\
\text { physician), } \\
\text { controlled }\end{array}$ & $\begin{array}{l}\text { Stage specific activity counselling } \\
\text { delivered by trained physicians (who } \\
\text { were paid to take part) following } \\
\text { written stage assessment in waiting } \\
\text { room + stage specific written } \\
\text { information, a written exercise } \\
\text { prescription, a free follow up clinic } \\
\text { visit at } 4 \text { weeks and non-staged } \\
\text { monthly mailings listing the benefits } \\
\text { of exercise and local facilities }\end{array}$ & $\begin{array}{l}\text { Routine care from physicians } \\
\text { who received no intervention } \\
\text { but were paid to take part }\end{array}$ & $\begin{array}{l}6 \text { weeks and } \\
8 \text { months }\end{array}$ & $\begin{array}{l}\text { At } 6 \text { weeks, } 89 \% \text { of intervention group and } \\
74 \% \text { of control group were in preparation or } \\
\text { action stage }(p<0.001) \text {. } 27 \% \text { of intervention } \\
\text { group and } 21 \% \text { of control group met activity } \\
\text { recommendations ( } 30 \text { minutes of moderate } \\
\text { exercise on } 5+\text { days per week or } 20 \text { minutes } \\
\text { of vigorous exercise on } 3+\text { days per week) } \\
\text { ( } p=0.27) \text {. } \\
\text { At } 8 \text { months, } 79 \% \text { of intervention group and } \\
88 \% \text { of control group were in preparation or } \\
\text { action stage }(p=0.07) .28 \% \text { of intervention } \\
\text { group and } 23 \% \text { of control group met activity } \\
\text { recommendations }(p=0.41) \text {. }\end{array}$ & Yes & No \\
\hline $\begin{array}{l}\text { Newcastle } \\
\text { exercise } \\
\text { project }^{23}\end{array}$ & $\begin{array}{l}442 \text { of } 523(85 \%) \text { sedentary } \\
\text { adults recruited in primary care } \\
\text { either opportunistically at } \\
\text { appointments or via mailed } \\
\text { invitations to participate }\end{array}$ & UK & $\begin{array}{l}\text { Randomised (by } \\
\text { individual), } \\
\text { controlled }\end{array}$ & $\begin{array}{l}\text { TTM based activity counselling } \\
\text { delivered by trained lifestyle advisor } \\
\text { +/- financial incentive. Four } \\
\text { intervention groups: one interview, } \\
\text { one interview plus tokens for free use } \\
\text { of local leisure facilities (financial } \\
\text { incentive), six interviews or six } \\
\text { interviews plus financial incentive }\end{array}$ & $\begin{array}{l}\text { Routine care - no further } \\
\text { intervention from study team }\end{array}$ & $\begin{array}{l}3 \text { and } 12 \\
\text { months }\end{array}$ & $\begin{array}{l}\text { At } 3 \text { months, } 55 \% \text { of most intensive } \\
\text { intervention group (six interviews \& financial } \\
\text { incentive) and } 38 \% \text { of combined intervention } \\
\text { groups showed improved activity scores } \\
\text { compared with } 16 \% \text { of controls ( } p=0.001 \text { ). } \\
\text { At } 12 \text { months, no intergroup differences ( } 23 \% \\
\text { of controls and } 26 \% \text { of combined intervention } \\
\text { groups showed increased activity scores, } \\
\text { p }>0.05 \text { ). }\end{array}$ & Yes & No \\
\hline $\begin{array}{l}\text { Marcus ef } \\
\text { a } \text { p }^{4} \text { and Bock } \\
\text { et a } \text { P }^{5}\end{array}$ & $\begin{array}{l}150 \text { of } 194(77 \%) \text { sedentary } \\
\text { adults recruited through } \\
\text { newspaper advertisements }\end{array}$ & USA & $\begin{array}{l}\text { Randomised (by } \\
\text { individual), } \\
\text { controlled }\end{array}$ & $\begin{array}{l}\text { Computer generated TTM based } \\
\text { individualised written activity } \\
\text { counselling compiled from a large } \\
\text { bank of standardised messages in } \\
\text { response to individuals reported } \\
\text { stage of activity change and current } \\
\text { activity levels + stage specific written } \\
\text { activity information (as used in Jump } \\
\text { Start to Health't } \\
\text { and } 3 \text { months sent at baseline, } 1\end{array}$ & $\begin{array}{l}\text { One of five non-staged written } \\
\text { activity information developed } \\
\text { by American Heart } \\
\text { Association and of similar } \\
\text { length to intervention } \\
\text { information }\end{array}$ & $\begin{array}{l}1,3,6 \text { and } \\
12 \text { months }\end{array}$ & $\begin{array}{l}\text { At } 6 \text { months, intervention group reported an } \\
\text { average of } 151.4 \text { minutes of activity/week } \\
\text { compared to } 97.6 \text { in control group ( } p<0.01 \text { ) } \\
\text { (improved from } 5.5 \text { and } 20.0 \text { minutes } \\
\text { respectively at baseline). } 43.6 \% \text { of intervention } \\
\text { group and } 18.1 \% \text { of control groups reached } \\
\text { recommended levels of activity ( } 30 \text { minutes on } \\
5 \text { or more days/week) ( } p<0.05 \text { ). } 42.3 \% \text { of } \\
\text { intervention group and } 18.8 \% \text { of control group } \\
\text { reached action stage of activity change } \\
\text { (p<0.05). } \\
\text { At } 12 \text { months, intervention group reported an } \\
\text { average of } 187 \text { minutes of activity/ week } \\
\text { compared to } 133 \text { in control group ( } \mathrm{p}=0.1) \text {. } \\
42 \% \text { of intervention group and } 25 \% \text { of control } \\
\text { groups reached recommended levels of activity } \\
\text { (p<0.05). } 45.1 \% \text { of intervention group and } \\
23.5 \% \text { of control group reached } \\
\text { action/maintenance stage of activity change } \\
(p<0.05) \text {. }\end{array}$ & Yes & Yes \\
\hline $\begin{array}{l}\text { Jump start to } \\
\text { health }{ }^{28}\end{array}$ & $\begin{array}{l}903 \text { of } 1559(58 \%) \text { adults in all } \\
\text { stages of activity change, } \\
\text { recruited from worksites involved } \\
\text { in a wider health promotion } \\
\text { intervention, exact recruitment } \\
\text { method not stated }\end{array}$ & USA & $\begin{array}{l}\text { Randomised (by } \\
\text { individual), } \\
\text { controlled }\end{array}$ & $\begin{array}{l}\text { Stage specific written activity } \\
\text { information on how to start and } \\
\text { continue physical activity and } \\
\text { facilities in their area - one pamphlet } \\
\text { for each stage of change. } \\
\text { Appropriate stage pamphlet } \\
\text { delivered at baseline, and pamphlet } \\
\text { for next consecutive stage delivered } \\
\text { at one month }\end{array}$ & $\begin{array}{l}\text { Two of five non-staged, } \\
\text { "action orientated" written } \\
\text { activity pamphlets developed } \\
\text { by American Heart } \\
\text { Association and of similar } \\
\text { length to intervention } \\
\text { information delivered at } \\
\text { baseline and one month }\end{array}$ & 3 months & $\begin{array}{l}\text { Overall, } 31 \% \text { of subjects showed stage } \\
\text { progression: } 37 \% \text { of intervention group and } \\
27 \% \text { of control group }(p<0.01) \text {. Overall, } 13 \% \\
\text { of subjects showed stage regression : } 11 \% \text { of } \\
\text { intervention group and } 15 \% \text { of control group. } \\
\text { No significant effect of intervention on overall } \\
\text { activity levels but those who showed stage } \\
\text { progression, showed an average increase from } \\
39 \text { to } 115 \text { minutes of activity/week. }\end{array}$ & Yes & N/A \\
\hline
\end{tabular}


Table 2 continued

\begin{tabular}{|c|c|c|c|c|c|c|c|c|c|}
\hline \multirow[b]{2}{*}{ Project } & \multirow[b]{2}{*}{$\begin{array}{l}\text { Nature of sample completing } \\
\text { study }\end{array}$} & \multirow[b]{2}{*}{ Country } & \multirow[b]{2}{*}{ Design } & \multirow[b]{2}{*}{ Experimental intervention } & \multirow[b]{2}{*}{ Control condition } & \multirow[b]{2}{*}{$\begin{array}{l}\text { Follow up } \\
\text { period }\end{array}$} & \multirow[b]{2}{*}{ Results } & \multicolumn{2}{|c|}{ Effective* } \\
\hline & & & & & & & & $\begin{array}{l}\text { Short } \\
\text { term* }\end{array}$ & $\begin{array}{l}\text { Long } \\
\text { ferm }\end{array}$ \\
\hline $\begin{array}{l}\text { Project active } \\
\text { 29-31 }\end{array}$ & $\begin{array}{l}190 \text { of } 235(81 \%) \text { sedentary } \\
\text { adults recruited via mass media, } \\
\text { word of mouth, and recontact of } \\
\text { participants in previous studies }\end{array}$ & USA & $\begin{array}{l}\text { Randomised (by } \\
\text { individual), } \\
\text { controlled }\end{array}$ & $\begin{array}{l}\text { TTM based group activity counselling } \\
\text { in groups of } 10-13 \text {, weekly to week } \\
16 \text {, fortnightly to week } 24 \text {, monthly to } \\
\text { week } 52 \text { and bimonthly to week } 104 \text {. } \\
\text { Monthly assessment of stage of } \\
\text { activity change and delivery of } \\
\text { appropriate stage matched activity } \\
\text { pamphlet. Significant effort made to } \\
\text { ensure attendance including reminder } \\
\text { letters before and thank you letters } \\
\text { after meetings and phone calls to } \\
\text { non-attendees. }\end{array}$ & $\begin{array}{l}\text { Free gym membership for } 6 \\
\text { months. Three weeks of } \\
\text { closely supervised instruction } \\
\text { followed by less supervision } \\
\text { and long term planning } \\
\text { session with trainer at six } \\
\text { months including receipt of all } \\
\text { stage matched pamphlets } \\
\text { used in intervention group. } \\
\text { Participants encouraged to } \\
\text { attend at least three gym } \\
\text { sessions per week and } \\
\text { contacted by phone if } \\
\text { attended less than one session } \\
\text { in any one week. }\end{array}$ & $\begin{array}{l}6 \text { and } 24 \\
\text { months }\end{array}$ & 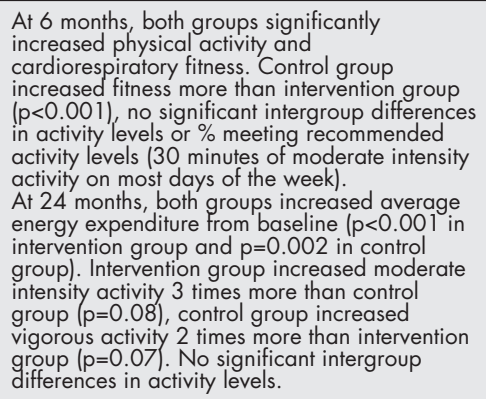 & No & No \\
\hline Naylor et $a^{\beta 2}$ & $\begin{array}{l}180 \text { of } 294(61 \%) \text { adults in all } \\
\text { stages of activity change, } \\
\text { recruited in primary care from } \\
\text { those attending routine health } \\
\text { checks }\end{array}$ & UK & $\begin{array}{l}\text { Non-randomised, } \\
\text { controlled }\end{array}$ & $\begin{array}{l}\text { TTM/non-TTM based brief (<5 } \\
\text { minutes) activity counnelling delivered } \\
\text { by practice nurse +/- stage specific } \\
\text { written activity information. Three } \\
\text { intervention groups: TMM based } \\
\text { counselling plus stage specific written } \\
\text { information; written information only; } \\
\text { non-TTM based brief activity } \\
\text { counselling. All participants received } \\
\text { information on, and discount } \\
\text { vouchers for, local leisure facilities. }\end{array}$ & $\begin{array}{l}\text { Standard practice advice } \\
\text { including asking participants } \\
\text { about current activity levels } \\
\text { and giving advice at nurse's } \\
\text { discretion. }\end{array}$ & $\begin{array}{l}2 \text { and } 6 \\
\text { months }\end{array}$ & $\begin{array}{l}\text { At } 2 \text { months, overall, } 25 \% \text { showed stage } \\
\text { progression compared with baseline } \\
\text { (p=0.003). No intergroup differences in stage } \\
\text { progression or activity levels. } \\
\text { At } 6 \text { months, overall, } 20 \% \text { showed stage } \\
\text { progression compared with baseline } \\
\text { (p=0.009). No intergroup differences in stage } \\
\text { progression or activity levels. } \\
\text { Stage progression was not significantly } \\
\text { associated with increased activity levels. No } \\
\text { effect of time or intervention on activity levels. }\end{array}$ & No & N/A \\
\hline $\begin{array}{l}\text { Peterson and } \\
\text { Aldana }^{33}\end{array}$ & $\begin{array}{l}527 \text { of } 784(67 \%) \text { adults in all } \\
\text { stages of activity change } \\
\text { recruited by random sampling of } \\
\text { all employees of a large } \\
\text { telecommunications firm }\end{array}$ & USA & $\begin{array}{l}\text { Randomised (by } \\
\text { individual), } \\
\text { controlled }\end{array}$ & $\begin{array}{l}\text { Stage specific written activity } \\
\text { information or generic wirten activity } \\
\text { information. Two intervention groups: } \\
\text { stage specific written information } \\
\text { drawing on stages and processes of } \\
\text { change or generic written information } \\
\text { focusing on known benefits of } \\
\text { exercise and recommended levels. } \\
\text { Both interventions similar in size, } \\
\text { layout, and length. }\end{array}$ & No intervention & 6 weeks & $\begin{array}{l}\text { Subjects receiving staged information increased } \\
\text { activity by } 13 \% \text {, those receiving generic } \\
\text { information increased activity by } 1 \% \text { and } \\
\text { control group decreased activity by } 8 \% \\
\text { (p }<0.05 \text { ). } 33 \% \text { of staged intervention group } \\
\text { showed stage progression, } 19 \% \text { of generic } \\
\text { intervention, and } 14 \% \text { of control group } \\
(p<0.0001) \text {. }\end{array}$ & Yes & N/A \\
\hline $\begin{array}{l}\text { Change of } \\
\text { hearr }^{34-36}\end{array}$ & $\begin{array}{l}473 \text { of } 699(68 \%) \text { adults with } \\
\text { BMl>25 and taking part in less } \\
\text { than } 12 \text { exercise sessions in last } \\
\text { month recruited in primary care } \\
\text { as part of multiple risk factor } \\
\text { intervention project (targeting } \\
\text { overweight and sedentary, } \\
\text { smoking, high cholesterol) }\end{array}$ & UK & $\begin{array}{l}\text { Randomised (by } \\
\text { GP practice), } \\
\text { controlled }\end{array}$ & $\begin{array}{l}\text { TTM based activity counselling ( } 2 \text { or } \\
3 \text { sessions - depending on number of } \\
\text { risk factors - of } 20 \text { minutes each) and } \\
1 \text { or } 2 \text { follow up phone calls } \\
\text { delivered by practice nurses }\end{array}$ & $\begin{array}{l}\text { Counselling from practice } \\
\text { nurses not trained in TTM } \\
\text { based counselling }\end{array}$ & $\begin{array}{l}4 \text { and } 12 \\
\text { months }\end{array}$ & $\begin{array}{l}\text { At } 4 \text { months, } 32 \% \text { of intervention and } 24 \% \text { of } \\
\text { control subjects were in action /maintenance: } \\
\text { odds of having moved into action/maintenance } \\
\text { stage in intervention compared with control } \\
\text { group was } 1.89(95 \% \text { Cl= } 1.07,3.36 \text { ). } \\
\text { lntervention subjects had increased the number } \\
\text { of sessions of exercise they undertook to } 169 \% \\
\text { of baseline, control subjects had to decreased } \\
\text { to } 64 \% \text { of baseline. } \\
\text { At } 12 \text { months, } 31 \% \text { of intervention and } 29 \% \text { of } \\
\text { control subbects in action/maintenance stage: } \\
\text { odds ratio } 1.68 \text { (195\% Cl=1.08, } 2.61) \text {. } \\
\text { lntervention subjects had increased the number } \\
\text { of sessions of exercise they undertook to } 146 \% \\
\text { of baseline, control subjects had to decreased } \\
\text { to } 89 \% \text { of baseline. }\end{array}$ & Yes & Yes \\
\hline
\end{tabular}




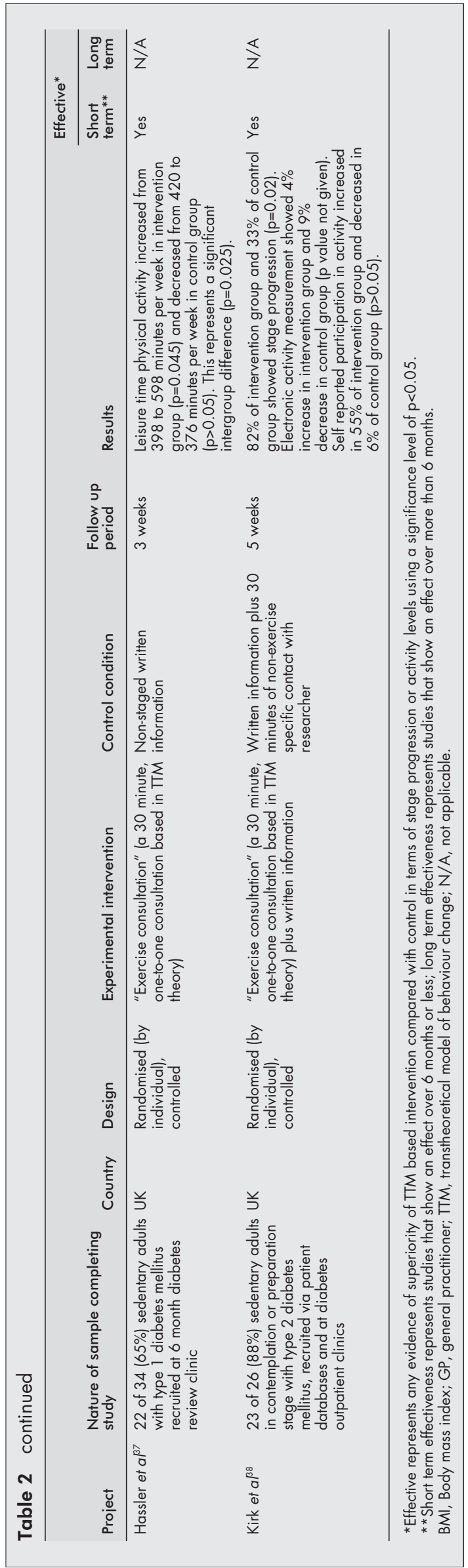

benefit from a staged intervention. The study is therefore of limited generalisability, and it cannot be clear that exercise consultations are truly staged if they are only applicable to people in particular stages of activity change.

\section{Project PACE ${ }^{16-19}$}

The PACE (physician based assessment and counselling for exercise) intervention has been assessed in two different trials. It has been found to be acceptable to both patients and doctors $^{18}$ and entails a realistic procedure whereby doctors are trained to deliver brief, TTM based activity counselling to patients, based on the results of an initial written assessment completed by patients in the waiting room. The first evaluation of the PACE trial ${ }^{16-18}$ (listed in table 2 as PACE 1) used only motivated doctors to deliver the intervention and used patients of doctors selected for their lack of interest in activity promotion as a control group. Although this procedure will amplify any effect of the intervention, such a control condition may not represent routine care as it is experienced by the average patient. Furthermore, PACE 1 only assessed the effect of the intervention on those initially in the contemplation stage of activity change-a limited interpretation of the TTM, as discussed above.

A concurrent analysis of the effect of the PACE intervention on a number of psychological mediators of activity change identified by the TTM was also made. ${ }^{17}$ This found that changes in measured constructs explained about $9 \%$ of the change in activity measured, suggesting that the PACE intervention has a measurable effect on the mediators of change as identified by the TTM.

The second PACE trial (PACE 2) randomly assigned doctors to intervention or control groups and reported results on patients initially in all stages of activity change. This study again found that the intervention was most effective in those initially in the contemplation stage of activity change, suggesting that the PACE intervention works better in particular groups. Truly staged interventions would be expected to be equally effective in all subjects.

\section{Physically active for life lo-22 $^{2}$}

The Physically active for life intervention used a similar protocol and intervention to the PACE studies, although it targeted people over 50 and added a four week review visit and stage specific, written information to the intervention protocol. The review visit was free to patients in the trial but would represent a considerable cost if implemented widely.

As with Project PACE, a concurrent study assessed the impact of the intervention on a number of theoretically determined mediators of exercise change. ${ }^{21}$ Although some differences were seen between the groups at six weeks, these were not sustained at eight months.

\section{The Newcastle exercise project ${ }^{23}$}

This study compared the effect of brief and more intensive TTM based activity counselling with and without the addition of financial incentives. Despite the fairly intensive intervention delivered to some participants (up to six counselling sessions), no long term effects on activity levels were reported.

Unlike many other studies reviewed, physical measures of lung function and fitness were made of all participants in this study. This assessment procedure is a significant intervention in itself and may account for the increase in overall activity levels seen throughout the study groups.

\section{Studies of Marcus et $\mathrm{al}^{24}$ and Bock et $\left.\mathbf{a}\right|^{25}$}

This study built on the finding that smokers receiving individually tailored letters were significantly more likely to give up smoking than those receiving a standard letter. ${ }^{26}{ }^{27}$ The intervention was innovative and potentially low cost, requiring little trained staff time after the initial development of the computerised messages and programme. 
Participants were recruited by newspaper advertisements, which may account for the rather unrepresentative sample, consisting primarily of white, middle class, non-smoking women with at least a high school level of education. However, the programme is the first reviewed here to report evidence of long term effectiveness of a TTM based activity promotion intervention.

\section{Jump start to health study ${ }^{28}$}

This worksite based study made a randomised, controlled assessment of the effect of the stage specific, written, activity promotion pamphlets developed for a previous uncontrolled, study. ${ }^{11}$ As with other written interventions reviewed, this was a relatively low cost intervention which would be fairly easy to incorporate into clinical practice.

However, as with other worksite interventions, ${ }^{14}$ there is a possibility of contamination leading to a dilution of the real effect of the intervention. As with other studies, those completing the intervention were more likely to be white collar workers and regularly active at baseline, limiting the generalisability of the results.

\section{Project active $^{529-31}$}

Project active assessed the effect, in terms of activity adoption and adherence and cardiovascular risk, of a traditional, structured, gym based, exercise programme compared with a TTM based programme advocating lifestyle activity. One of the important outcomes of this study was to confirm that moderate intensity lifestyle exercise is as effective, in terms of cardiovascular risk reduction, as vigorous, structured activity sessions. However, the study did not detect any additional benefit of the TTM based behavioural programme over and above the structured programme, in either the short or long term.

The behavioural intervention in Project ctive was, perhaps, more intensive than any other reviewed here and therefore of limited cliniacal applicability. Participants were asked to attend more than 30 group counselling sessions over a two year period. Despite this, the behavioural intervention was found to be more cost effective than the structured programme. $^{31}$

\section{Study of Naylor et al $\mathbf{l}^{32}$}

This non-randomised trial is the first study reviewed here that compared TTM based counselling and generic activity counselling. This process should allow the specific TTM component of counselling to be assessed. The intervention was also pragmatic and realistic, with practice nurses undertaking only very brief ( five minutes) counselling.

Despite showing an overall effect on stage progression, the study did not show any additional benefit of the TTM based interventions over the non-TTM based counselling. This seriously questions the importance that has been placed on the type and theoretical foundation of counselling and suggests that any counselling, if well delivered, can have some effect on activity levels.

\section{Study of Peterson and Aldana ${ }^{33}$}

This study compared stage matched, written, activity promotion information with generic, activity promotion information and no information. This was the only study reviewed here that used a no intervention control group as well as the more usual non-staged intervention control group. It found a stepped effect of the generic and stage matched information, suggesting that, although generic information can have some effect on activity levels, stage matched information is more effective.

However, the study was worksite based, leading to possible contamination, had a very short follow up period, and only managed to retain a rather unrepresentative sample of white, female, well educated participants.

\section{Change of heart study ${ }^{34-36}$}

This study tackled inactivity as part of a multiple cardiovascular risk factor intervention trial. Practice nurses were trained to deliver TTM based counselling for all three risk behaviours (sedentary, high fat diet, smoking) together rather than solely focusing on activity, as in other trials. This procedure was compared with counselling delivered by nurses not trained in TTM theory. Despite having significant recruitment and retention problems such that the power requirements of the study were not met, the intervention was found to be successful in promoting both activity adoption and adherence. Unlike previous work, ${ }^{32}$ it showed an effect of TTM based counselling over and above generic activity counselling, suggesting that the theoretical basis of counselling is important.

\section{Study of Hassler et $\left.a\right|^{37}$}

This was a small, randomised, controlled trial of the use of exercise consultations ${ }^{15}$ in sedentary people with type 1 diabetes mellitus. The study was small (only 22 subjects completed), and the follow up period (three weeks) was very short. Larger and longer studies of exercise consultations are needed to confirm whether this relatively intensive and potentially costly intervention (30 minutes of trained counsellor time) should be used more widely.

\section{Study of Kirk et $\left.a\right|^{38}$}

This was a small pilot study of the utility of exercise consultation $^{15}$ in sedentary patients with type 2 diabetes mellitus. Unlike much previous work, this study controlled for the effect of contact time with counsellors by engaging patients in the control group in 30 minutes of non-activity related discussions about their diabetes. Again, the study was short and small, and the authors acknowledge the need for larger trials of exercise consultations.

\section{DISCUSSION}

We found 26 papers documenting 16 TTM based activity promotion interventions. These may not be all such reports published but we believe they represent the core work in this area.

The TTM based activity promotion programmes reviewed generally found some short term benefit in terms of activity levels or stage of activity change. Longer term effects seem to be harder to achieve and this questions the overall benefit of these programmes (table 2). A number of methodological and theoretical issues are common to the projects reviewed. We discuss these here and identify a number of areas for further work.

There was significant heterogeneity in the programmes reviewed in terms of intervention design, recruitment methods, participants recruited, outcome measures, length of follow up, and results reported making comparison difficult. In particular, this heterogeneity highlights the many different ways in which the TTM can be interpreted for intervention design. Many different TTM based interventions were reviewed, and the important question may not be "are TTM based activity promotion interventions effective?" but "which TTM based activity promotion interventions are effective?". Only one of the studies reviewed ${ }^{12}$ attempted to compare different methods of delivering TTM based interventions. More comparative studies of TTM based interventions of known effectiveness should be made.

A further element of TTM interpretation, in terms of intervention design, is identified by the second PACE trial, ${ }^{19}$ which reported that the intervention was most effective in people originally in the contemplation stage of activity change. Although this suggests that sedentary persons, in particular, were responding to the intervention, if a stage matched programme is to be claimed to be effective, it must be effective in people in all stages of activity change. Programmes based 
on the TTM that provide a separate intervention for people in each of the different stages of activity change are complex and effectively comprise up to five different interventions. There may be a need to trial each stage matched intervention separately to ensure optimum design before combining interventions into fuller programmes. At the same time, it is important not to lose sight of the fact that the TTM advocates that all subjects can derive some benefit from appropriately designed interventions and that an effective intervention must be developed for people in each separate stage of change. The TTM promotes inclusion, and there is a need for more studies that recruit subjects in all stages of activity change, or at least all those before maintenance, rather than just those who are initially sedentary.

A number of the studies reviewed reported that, despite recruitment of initially representative samples, the subjects who completed all follow up measurements were primarily white, middle class, female, and regularly active ${ }^{14} 1924252833$ This problem may be exacerbated by the reliance that intervention studies must make on volunteer participants. It has been reported that non-random sampling strategies tend to under-recruit subjects in the precontemplation stage of activity change. ${ }^{8}$ Differential retention limits the generalisability of results, but also highlights the problems of accessing and retaining those who may benefit most from the interventions. Further, innovative strategies to recruit and retain hard to reach population groups need to be devised.

A number of studies reported an intervention effect on stage of activity change without a concurrent effect on actual activity levels. ${ }^{19} 22832$ Although this is perfectly possible (table 1) and of some interest and relevance, the ultimate aim of activity promotion interventions must be to increase activity adoption and adherence. Stage progression is only an intermediate in this process, and there is no guarantee that it makes a good proxy for eventual activity adoption and adherence; people are known to progress backwards as well as forwards through the stages of change. ${ }^{39}$ Further studies should be careful to include activity as well as stage of change outcome measures.

The difference between activity adoption and adherence has been highlighted previously, ${ }^{40}$ as well as the finding that long term adherence to increased activity levels is much harder to achieve than short term adoption. ${ }^{6}$ This review confirms this finding: $73 \%$ of short term studies reported a positive effect of TTM based interventions over control conditions, whereas only $29 \%$ of long term studies did. The review also identifies that longer term studies are much less likely to be performed: less than half of the studies reviewed carried out follow up beyond six months. Future studies must give priority to performing long term follow up and achieving activity adherence as well as adoption.

A number of studies reviewed found that, although there was no additional benefit of the TTM based intervention over the control condition, significant increases in activity, or stage of activity change, was seen in all groups. ${ }^{12293241}$ This suggests that even a brief measurement intervention can have some effect and should perhaps be exploited in future intervention development.

All of the studies reviewed are hampered by physical activity and stage of activity change measurement problems. ${ }^{842} 43$ Numerous different methods of measuring physical activity were used by the studies reviewed including various self report measures (almost all studies), physical fitness assessment, ${ }^{23} 29$ and electronic motion monitors. ${ }^{38}$ None of these methods are necessarily valid, and all measure slightly different constructs. In addition, many different measures of stage of activity change were used which relied on different precise definitions of the different stages. There is a need for standardised measures of both physical activity and stage of activity change.

Seven of the programmes reviewed used some sort of TTM based activity counselling. It is very difficult to confirm that counselling interventions are delivered as intended, particularly when a number of different "counsellors" are used. The effectiveness of counselling will not only depend on training given, but also on rapport built and the wider skills and tools that each counsellor has available to them. Ensuring a consistent intervention across counsellors is almost impossible and limits the generalisability of any counselling intervention. ${ }^{44}$ Checks of treatment fidelity should be introduced to confirm that TTM based interventions are delivered as intended.

Related to this is the limited attempts that have been made to confirm that it is the TTM based component of activity counselling that is effective. As noted, many other variables, other than the theoretical grounding of counselling, may influence its effectiveness. Only two studies reviewed ${ }^{32}{ }^{35} \mathrm{com}-$ pared TTM based activity counselling with generic counselling. However, these studies had conflicting results on the benefit of TTM based counselling over generic counselling. Further work is needed to determine whether TTM based counselling is any more effective than well delivered, generic, activity promotion counselling.

One final aspect of study design that has been overlooked by research to date is the possibility of testing not whether stage matched interventions are more effective than non-stage matched interventions, but whether stage matching is particularly important. This could be investigated by randomising subjects to receive either an intervention matched to their stage of activity change or a randomly allocated, staged intervention.

Finally, the complexity of physical activity behaviour should not be underestimated. Individuals appear to treat different forms of activity as entirely different behaviours, and there is evidence that they can be in different stages of activity change for different activities. ${ }^{45}$ Current measures of stage of activity change do not take this into account and interventions may also overlook it.

\section{Conclusions}

We have identified and critically reviewed 16 TTM based activity promotion interventions. From the evidence presented, it appears that TTM based activity promotion interventions are, in general, more effective than non-staged interventions in promoting short term activity adoption. The longer term effect of TTM based interventions on activity adherence has not been as thoroughly explored but preliminary findings are disappointing.

Future work in this area should focus on:

- Comparative studies to determine the most effective TTM based activity promotion interventions

- Careful design and evaluation of interventions to confirm that people in each stage of activity change receive a truly tailored and effective intervention

- Innovative strategies to recruit and retain candidates who are hard to reach-for example, men, those in the precontemplation stage of activity change, members of ethnic minorities, and socially disadvantaged groups

- Including people in all stages of activity change rather than just those who are initially sedentary or in the pre-action stages of activity change

- Measuring physical activity as well as stage of activity change and focusing on activity more than stage of change as an outcome measure

- Achieving adherence, as well as adoption, of increased activity levels and following up study participants long enough to confirm this

- Investigating the effects of brief measurement interventions

- Developing standardised measures of physical activity and stage of activity change 


\section{Take home message}

TTM based activity promotion programmes are effective in promoting adoption of physical activity in the short term. Evidence on longer term adherence is limited but currently disappointing.

\section{- Ensuring treatment fidelity}

- Assessing whether TTM based activity promotion counselling is any more effective than well delivered, generic counselling

- Exploring whether a group of staged interventions allocated on the basis of the stage of activity change are any more effective than random allocation of the same group of interventions

- Acknowledging the complexities of physical activity behaviour and incorporating this into interventions and outcome measures

\section{ACKNOWLEDGEMENTS}

An earlier version of this review was submitted by Jean Adams as partial fulfilment of the requirements for the degree of MBBS at the University of Newcastle upon Tyne, UK. We thank Jane Harland and two anonymous reviewers for helpful comments on an earlier draft of this review.

\section{Authors' affiliations}

J Adams, $\mathbf{M}$ White, School of Population and Health Sciences, University of Newcastle upon Tyne Medical School, Newcastle upon Tyne NE2 4HH, UK

\section{REFERENCES}

1 Turner-Warwick M, Pentecost B, Jones J, et al. Medical aspects of exercise: summary of a report of the Royal College of Physicians. J R Coll Physicians Lond 1991;25:193-6.

2 Whitehead M. Physical activity. Health Update 1995;5

3 The Sports Council, The Health Education Authority. Allied Dunbar national fitness survey. Northampton, 1992.

4 Prochaska J, DiClemente C. Transtheoretical therapy: toward a more integrative model of change. Psychotherapy: Theory, Research and Practice 1982;19:276-88.

5 Dunn A, Marcus B, Kampert J, et al. Reduction in cardiovascular disease risk factors: 6-month results from Project Active. Prev Med 1997; 26:883-92.

6 Dishman R. Increasing and maintaining exercise and physical activity. Behavioural Therapy 1991;22:345-78.

7 Buxton K, Wyse J, Mercer T. How applicable is the stages of change model to exercise behaviour? A review. Health Educ J 1996;55:239-57.

8 Marshall S, Biddle S. The transtheoretical model of behaviour change: a meta-analysis of applications to physical activity and exercise. Annals of Behavioural Medicine 2001;23:229-46.

9 Ashworth P. Breakthrough or bandwagon? Are interventions tailored to stage of change more effective that non-staged interventions? Health Educ J 1997:56: 166-74.

10 NIH Consensus Development Panel on Physical Activity and Cardiovascular Health. Physical activity and cardiovascular health. JAMA 1996;276:241-6.

11 Marcus B, Banspach S, Lefebvre R, ef al. Using the stages of change model to increase the adoption of physical activity among community participants. Am J Health Promot 1992;6:424-9.

12 Graham-Clarke P, Oldenburg B. The effectiveness of a general practice based physical activity intervention on patient physical activity status. Behaviour Change 1994;11:132-44.

13 Rose G. The strategy of preventative medicine. Oxford: Oxford University Press, 1993.

14 Cardinal B, Sachs M. Increasing physical activity using the stages of change model and mail-delivered exercise programs. Res Q Exerc Sport 1994; (Mar suppl):A-45

15 Loughlan C, Mutrie N. Conducting an exercise consultation: guidelines for health professionals. Journal of the Institute of Health Education 1995;33:78-82.

16 Calfras K, Long B, Sallis J, et al. A controlled trial of physician counselling to promote the adoption of physical activity. Prev Med 1996;25:225-33.
17 Calfras K, Sallis J, Oldenburg B, et al. Mediators of change in physical activity following an intervention in primary care: PACE. Prev Med 1997; 26:297-304

18 Long B, Calfras K, Wooten W, et al. A multi-site field test of the acceptability of physical activity counselling in primary care: Project PACE. Am J Prev Med 1996;12:73-81.

19 Norris S, Grothaus L, Buchner D, et al. Effectiveness of physician based assessment and counselling for exercise in a staff model HMO. Prev Med 2000;30:513-23.

20 Pinto B, Goldstein M, DePue J, et al. Acceptability and feasibility of physician based activity counselling. Am J Prev Med 1998;15:95-102.

21 Pinto B, Lynn H, Marcus B, et al. Physician based activity counselling: intervention effects on mediators of motivational readiness for physical activity. Annals of Behavioural Medicine 2001;23:2-10.

22 Goldstein M. Pinto B, Marcus B, et al. Physician based physical activity counselling for middle aged and older adults: a randomized trial. Annals of Behavioural Medicine 1999;21:40-7.

23 Harland J, White M, Drinkwater C, et al. The Newcastle exercise project: a randomised controlled trial of methods to promote physical activity in primary care. BMV 1999:319:828-32

24 Marcus B, Bock B, Pinto B, et al. Efficacy of an individualized, motivationally-tailored physical activity intervention. Annals of Behavioural Medicine 1998;20:174-80.

25 Bock B, Marcus B, Pinto B, et al. Maintenance of physical activity following an individualized motivationally tailored intervention. Annals of Behavioural Medicine 2001;23:79-87.

26 Prochaska J, DiClemente C, Velicer W, et al. Standardised, individualized, interactive, and personalized self-help programs for smoking cessation. Health Psychol 1993;12:399-405.

27 Strecher V, Kreuter M, Den Boer D, et al. The effects of computer-tailored smoking cessation messages in family practice settings. J Fam Pract 1994;39:262-70.

28 Marcus B, Emmons K, Simkin-Silverman L, et al. Evaluation of motivationally tailored vs. standard self-help physical activity interventions at the workplace. Am J Health Promot 1998;12:246-53.

29 Dunn A, Marcus B, Kampert J, et al. Comparison of lifestyle and structured interventions to increase physical activity and cardiorespiratory fitness. JAMA 1999;281:327-34.

30 Kohl H, Dunn A, Marcus B, et al. A randomized trial of physical activity interventions: design and baseline data from Project Active. Med Sci Sports Exerc 1998;30:275-83.

31 Sevick M, Dunn A, Morrow M, et al. Cost effectiveness of lifestyle and structured exercise interventions in sedentary adults: results of project ACTIVE. Am J Prev Med 2000;19:1-8.

32 Naylor $\mathbf{P}$, Simmonds $G$, Riddoch $C$, et al. Comparison of stage-matched and unmatched interventions to promote exercise behaviour in the primary care setting. Health Educ Res 1999;14:653-66.

33 Peterson T, Aldana S. Improving exercise behaviour: an application of the stages of change model in a worksite setting. Am J Health Promot 1999; 13:229-32

34 Hilton S, Doherty S, Kendrick T, et al. Promotion of healthy behaviou among adults at increased risk of coronary heart disease in general practice: methodology and baseline data from the Change of Heart study. Health Educ J 1999:58:3-16.

35 Steptoe A, Doherty S, Rink E, et al. Behavioural counselling in general practice for the promotion of healthy behaviour among adults at increased risk of coronary heart disease: randomised trial. $B M$ 1999;319:943-8.

36 Steptoe A, Kerry S, Rink E, et al. The impact of behavioural counselling on stage of change of fat intake, physical activity, and cigarette smoking in adults at increased risk of coronary heart disease. Am J Public Health 2001;91:265-9.

37 Hassler T, Fisher B, Maclntyre P, et al. Exercise consultation and physical activity in patients with type 1 diabetes. Practical Diabetes International 2000; 17:44-8.

38 Kirk A, Higgins L, Hughes A, et al. A randomized, controlled trial to study the effect of exercise consultation on the promotion of physical activity in people with type 2 diabetes: a pilot study. Diabetes UK 2001; 18:877-82.

39 Prochaska J, DiClemente C, Norcross J. In search of how people change. Am Psychol 1992;47:1 102-14.

40 Laitakari J, Vuori I, Oja P. Is long term maintenance of health-related physical activity possible? An analysis of concepts and evidence. Health Educ Res 1996;1 1:463-77.

41 Loughlan C, Mutrie N. An evaluation of the effectiveness of three interventions in promoting physical activity in a sedentary population. Health Educ J 1997;56:154-65.

42 Lamonte M, Ainsworth B. Quantifying energy expenditure and physical activity in the context of dose response. Med Sci Sports Exerc 2001;33(suppl 6):S370-8

43 Dishman $\mathbf{R}$. The measurement conundrum in exercise adherence research. Med Sci Sports Exerc 1994;26:1382-90.

44 Moncher F, Prinz R. Treatment fidelity in outcome studies. Clin Psychol $\operatorname{Rev} 1990 ; 11: 247-66$

45 Miilunpalo S, Nupponen R, Laitakari J, et al. Stages of change in two modes of health-enhancing physical activity: methodological aspects and promotional implications. Health Educ Res 2000;15:435-48. 